\title{
Impacts of desiccation on ecosystem services and household adaptation in the Okavango Delta, Botswana
}

\author{
Donald L. Kgathi, Gagoitseope Mmopelwa, Cornelis Vanderpost, Piotr Wolski \& \\ Moseki R. Motsholapheko
}

\begin{abstract}
River flow and inundation of floodplains support a variety of ecosystem services in the Okavango Delta in Botswana. However, river channel desiccation occurs for a number of years or permanently, resulting in adverse impacts on ecosystem services-dependent livelihood activities. This phenomenon is caused by changes in rainfall patterns as well as by shifts in flow distribution due to a number of factors. This study has investigated the relationship between adaptation to desiccation and ecosystem services which support livelihoods in the Okavango Delta. Research methods included the use of aerial photographs and satellite images, household survey, focus group discussions, hydrological modelling and the construction of scenarios on socio-economic impacts of desiccation. The results of the study showed that desiccation adversely affects various livelihood activities, particularly those based on ecosystem services such as flood recession agriculture, livestock farming and veld products collection. It is further revealed that this phenomenon is likely to increase in frequency and intensity in the future as a result of climate change. The paper posits that adaptation policies which support diversification of livelihood activities into those which are less dependent on ecosystem services should be promoted.
\end{abstract}

Keywords: Adaptation; climate variability; desiccation; ecosystem services; livelihoods; Okavango Delta.

Abbreviations: $\mathrm{CSO}=$ Central Statistics Office; $\mathrm{GCM}=$ General Circulation Models; IPCC=Intergovernmental Panel on Climate Change MA= Millennium Ecosystem Assessment; PET= potential evapo-transpiration

\section{Os impactos da dessecação sobre os serviços do ecossistema e a adaptação das famílias no delta do Okavango, Botsuana}

Resumo: O fluxo do rio e a inundação de várzeas favorecem uma variedade de serviços ecossistêmicos no delta do Okavango, em Botsuana. No entanto, a dessecação do canal do rio tem ocorrido por alguns anos ou permanentemente, resultando em impactos negativos sobre as atividades de subsistencia dependentes dos serviços do ecosistema. Este fenômeno é causado por alterações nos padrões pluviais, bem como por alterações na distribuição do fluxo, devido a uma série de factores. O presente estudo investigou a relação entre a adaptação e a dessecação e os serviços ecosistêmicos que apoiam os meios de subsistência no delta do Okavango. Os métodos de pesquisa incluiram o uso de fotografias aéreas e imagens de satélite, pesquisa domiciliar, discussões em grupo, modelagem hidrológica e a construção de cenários sobre os impactos sócio-econômicos da dessecação. Os resultados mostraram que a dessecação afeta negativamente várias atividades de subsistência, especialmente aquelas baseadas em serviços do ecossistema como a agricultura de recessão de inundação, a criação de gado e a coleta de produtos das savanas. Revelaram também que esse fenômeno tende a aumentar em frequência e intensidade no futuro, como resultado das mudanças climáticas. O documento propõe que sejam promovidas as políticas de adaptação que apoiam a diversificação das atividades de subsistência, para aqueles que são menos dependentes dos serviços dos ecossistemas.

Palavras-chave: adaptação; Delta Okavango; dessecação; meios de subsistência; serviços ecossistêmicos; variabilidade climática.

Received: 19 August 2013 - Accepted: 19 December 2013

\section{Introduction}

In recent years, research work on the interface between economics and other disciplines such as ecology and environmental science has received a great deal of attention because of the increasing pressure on natural resources. Research on ecosystem services is a notable example. The Millennium Ecosystem Assessment (MA) (2005) revealed that there is a decline in ecosystem services, worldwide, as a result of human activities. In most cases, those who are affected by the declining supply of ecosystem services are the poor who are more dependent on these services and therefore tend to be more vulnerable (Opschoor 2008, Shackleton et al. 2008, Daw et al. 2011). The decline in the well-being of the poor may further increase the pressure on ecosystem services, worsen poverty and lead to degradation of these services (MA 2005). Although policies and options for ecosystem management and improvement of well-being are available, they need radical changes (Munasinghe, 2008).
In the Okavango Delta of northern Botswana, river flow and inundation of floodplains support various livelihood activities. However, at variable locations within the Okavango wetlands, river channels have tended to dry up for a number of years or permanently, resulting in potentially adverse impacts on waterdependent livelihood activities such as fishing and flood recession agriculture. The latter is known as molapo in the local language of Setswana and it is a farming system which utilises soil moisture from the receding flood in the floodplains. 
Desiccation of river channels is caused by changes in rainfall patterns as well as by shifts in flow distribution due to a number of factors, including tectonic movements (earthquakes), hippo activity or, most commonly, blockages of channels by sediment and vegetation (Mendelsohn et al. 2010). Such distributional changes are superimposed over the flood-level (or overall wetness of the system) variations that occur from year to year and that are related to rainfall variability in the catchment and influence of antecedent conditions.

Models of climate change reveal that increased desiccation of river channels and floodplains is likely to be one of the possible impacts of climate change in the future (Wolski 2009, Wolski et al. 2012). Research in other developing countries reveals that the poor and marginalised groups are more vulnerable to such environmental change because they lack the means and resources to cope with or to adapt to this change (Shackleton et al. 2008). Although some climate change predictions forecast increased dessication in the Okavango Delta, only a few studies (Kgathi et al. 2007, Motsholapheko 2013) have documented the impact of flood flow changes on rural livelihoods or resources. There is also dearth of information on how households adapt to actual and anticipated changes on social and economic factors constraining or enhancing human adaptive capacity or vulnerability and on the cost associated with measures taken to adapt. Furthermore, differences in the level of reponsiveness or adaptive capacity by different households to climate change is not well understood.

This study investigates the impact of desiccation of river channels on ecosystem services supporting human livelihoods in the Okavango Delta in Botswana. The specific research objectives are: 1) to determine desiccation events and processes taking place, 2) to describe and explain the impacts of river desiccation on ecosystem services supporting human livelihoods, 3) to investigate the socio-economic mechanisms by which households and communities adapt to desiccation or anticipate to do so, 4) to assess the extent to which access to ecosystem services is mediated by social relations, 5) To detemine the private costs associated with adaptation measures, and 6) to develop scenarios for future socio-economic and environmental change and suggest the social and ecological implications.

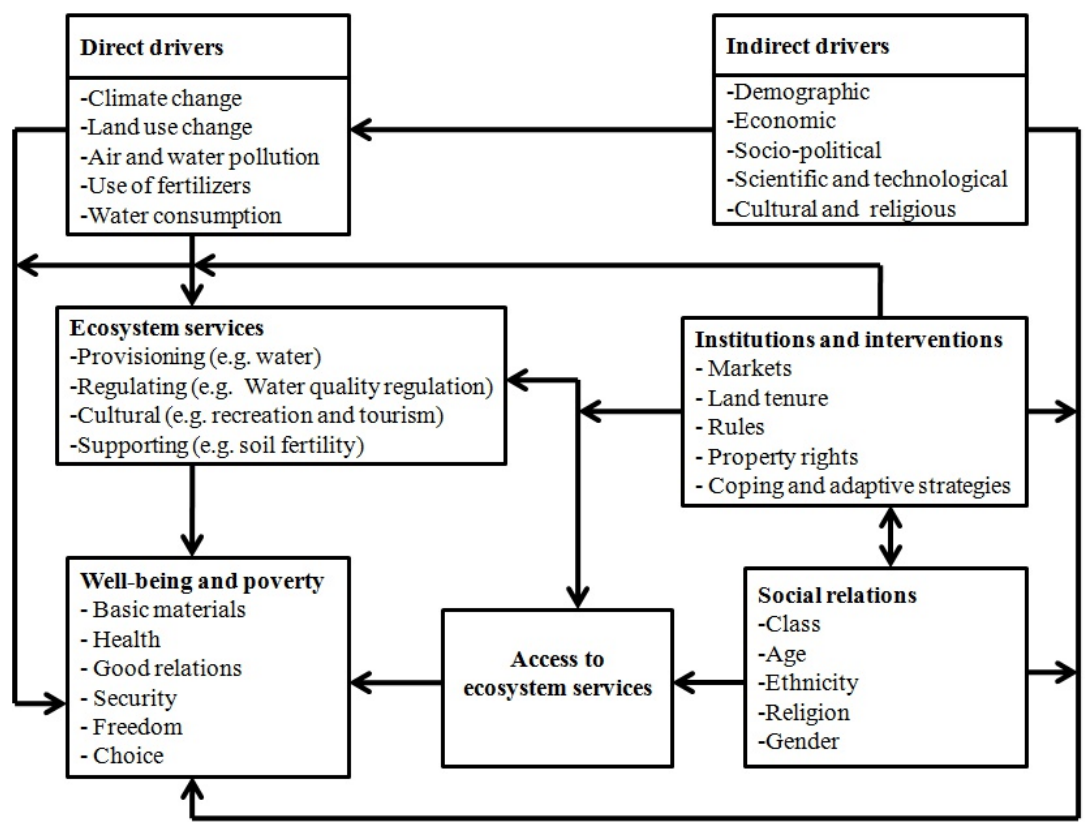

Fig. 1: A conceptual framework on the interface between ecosystem services and human well-being. Source: Developed based on constructs from MA (2005) and Ellis (2000).

\section{Conceptual framework and key concepts}

\section{Dynamics of ecosystem services and human well-being: a conceptual framework}

Figure 1 provides an analytical framework for conceptualising the results of this paper. The framework links human well-being with drivers of ecosystem change, factors which determine access to ecosystem services and how the political economy of access to ecosystem services may be influenced by institutions. The MA (2005) defines ecosystem services as "the benefits people obtain from ecosystems". The word "services" is used here as a simplified form of what some economists and ecologists refer to as "goods and services" (Costanza et al. 1997, Wallace 2007). The MA (2005) also categorises these services into provisioning, regulating, supporting, and cultural services. Though this classification has gained worldwide recognition, there is a concern that it does not differentiate processes from services; in other words it mixes the means for achieving services with the categories which are services in their own right (Boyd and Banzhaf 2006, Kroeger and Casey 2007, Wallace 2007).

Ecosystem services and human wellbeing may be directly or indirectly affected by factors known as ecosystem drivers. There are two types of ecosystem drivers: direct and indirect. A direct driver is one which directly influences ecosystem change and can therefore be easily identified and measured. Indirect drivers are diffuse in their impact on ecosystem change and cannot be easily identified and measured (Nelson et al. 2006). Figure 1 also shows that indirect drivers include demographic, economic, socio-political and cultural and religious factors which can lead to changes in direct drivers (e.g. climate change, landuse) which may result in changes in ecosystem services and human well-being and poverty. Drivers are also categorised as endogenous and exogenous; the former referring to those which can be influenced by the policy-maker and the latter being those which cannot be. Policy-makers are not in a position, for instance, to influence natural drivers such as climate change or drivers caused by global factors. In addition to direct and indirect drivers of change in ecosystem services, it is crucial to recognise that there are also underlying causes of ecosystem services degradation in the form of market and policy failures (Panayotou 1993, Perrings et al. 1992, Kroeger and Casey 2007).

The role played by ecosystem services in poverty alleviation is fundamental in understanding the political economy of access to human livelihoods. As a result of an increase in the demand for ecosystem services, the well-being of the 
poor is adversely affected; hence their vulnerability to poverty is increased. The MA (2005) defines poverty as the most deprived form of human well-being. Thus, well-being and poverty are at opposite ends of a continuum. Human well-being is multi-dimensional in nature; consisting of basic materials needed for good life such as sufficient food, clothing, shelter and sustainable livelihoods as well as non-material aspects such as good health, good social relations, security and freedom and choice (MA 2005). The concept of "sustainable livelihoods", one of the components of human well-being, is central to the theme of this paper. According to Ashley and Carney (1999), this concept introduces a new way of addressing poverty reduction by promoting people-centred and participatory development. The concept of "sustainable livelihoods" is operationalised through the "Sustainable Livelihood Framework" which provides insights into how livelihoods are conducted and secured in order to provide policy guidance on poverty alleviation and adaptation measures.

Factors mediating access to ecosystem services such institutions and social relations are also highlighted in Figure 1. In the context of this paper, institutions are defined as "rules, enforcement characteristics of rules, and norms of behaviour that structure the repeated interactions" (North, 1989), whereas social relations are the way in which individuals and households are positioned in society (Ellis, 2000). These constructs (social relations and institutions) have been borrowed from the Sustainable Livelihood Framework. According to this framework, institutions and social relations mediate access to resources, including ecosystem services (Ellis, 2000). They are also important in adaptation to the impacts of environmental shocks. The MA (2005) does not make it clear that the link between ecosystem services and human well-being is also determined by the extent to which access to ecosystem services is mediated by social relations and institutions (Ellis, 2000, Daw et al. 2011).

\section{Adaptation}

Adaptation is defined in different ways depending on the discipline (Smit and Wandel 2006, Kelly \& Adger 2000). The concept has its origins in the natural sciences, especially evolutionary ecology, where evolving organisms had to adapt to their surrounding environment. In the context of climate change science, Smit et al. (2000: 225) define adaptation as "adjustments in ecological-socialeconomic systems in response to actual or expected climatic stimuli, their effects or impacts". Thus, adaptation may be understood to mean human responses that may be used to reduce vulnerability or any action designed to take advantage of new opportunities created by climate change; or a process through which people reduce adverse effects on their health or general well-being. In this paper, adaptation is understood to mean human responses aimed at reducing vulnerability.

Adaptation strategies may be reactive in which case people respond to actual environmental changes that they have observed (Schneider et al. 2007, Stern 2006). Adaptation strategies may also be proactive or anticipatory in which case people take the necessary steps based on what they anticipate to happen (Umoh et al. 2004). Anticipatory changes may be based on model-based scenarios of long term changes in the environment (Adger et al. 2007). By adapting to anticipated impacts, people are forward-looking in action and hence they avoid being exposed to the future climate change risk. Anticipatory responses are more likely to be undertaken if good forecasts of likely future climate change exist (Dessler and Parson 2006).

Adaptation may also be categorised as planned or autonomous. Planned adaptation refers to a deliberate policy decision based on the knowledge that environmental change has occurred or anticipated to occur, whereas autonomous adaptation involves strategies that do not necessarily have to do with policy or government decision, but those which emanate from economic, social and political situations (Adger et al. 2003, Callaway 2003). Adaptation is thus an important policy option for reducing the adverse effects associated with the risks of climate change (Fussel and Klein 2006). In managed systems adaptation is a planned process, while it is mostly an unplanned process in unmanaged systems.

\section{Vulnerability}

The concept of vulnerability is also defined in different ways depending on the discipline. There are three main conceptualisations of vulnerability known as the global climate change, the risk hazard, and social constructivist (Fussel and Klein 2006). The global climate change framework defines vulnerability as "the degree to which a system is susceptible to, or unable to cope with, adverse effects of climate change, including climate variability and extremes (Intergovernmental Panel on Climate Change (IPCC) 2001: 995). The framework has two key aspects: 1) the external dimension of risks represented by the exposure of the system to the climate change stimuli 2) the internal aspects represented by the response of the system to climate stimuli. The latter depends on adaptive capacity of the system. The risk-hazard framework defines vulnerability in terms of doseresponse relationships whereby an exogenous hazard may have an adverse impact on the system (e.g. households or community or region). The social constructivist framework emphasises the well-being of society and political economy aspects in the analysis of vulnerability, asking questions such as who gets how much of the cake and why (Fussel and Klein, 2006). This paper adopts the global climate change conceptualisation of vulnerability.

\section{Study areas and methods}

\section{General study area}

Our general study area is situated in north-west Botswana and it mainly focuses on the Okavango Delta (including the distal areas of Boteti River sub-Basin) (Fig. 2), and it is one of the world's most pristine and least transformed tropical wetlands (Mendelsohn et al. 2010). Wildlife abundance has made it an international tourism destination, renowned for its tranquillity, natural beauty and near pristine environment in a world in which most wetlands have become heavily transformed.

The area has an approximate average annual precipitation of $450 \mathrm{~mm} / \mathrm{yr}$ defined by high inter-annual variability and, hence, it is described as semi-arid (Ministry of Finance and Development Planning (MFDP 2009). The soils of the study area are developed on the nutrientpoor and highly permeable Kalahari sand substratum. The annual flood originates from the high rainfall zone of the Angolan highlands and it is an important 




Fig. 2: Map of the Okavango Delta, Botswana showing the study villages.

driver of the Okavango ecosystem and its ecosystem services. The Okavango Delta and its terminal rivers is characterized by substantial natural fluctuations of flooding and flow that are related to highly variable inflows from the upper catchment in Angola. Flood variability occurs at a number of temporal scales from seasonal to inter-annual and multidecadal, with the latter being of a particular significance. Data from the Department of Water Affairs of the Botswana Ministry of Minerals, Energy and Water Resources indicates that in the 20th century, the Okavango system experienced the dry 1920-1940s, the wet $1960-1970$ s, and the dry $1980-1990$ s with inundation extents changing between the dry and wet phases by a factor of 2 . This variability in flooding is only magnified within the evaporation-dominated Okavango Delta, resulting in decadal and longer periods of no flow or regular flow conditions in the Thamalakane and Boteti
River systems, located downstream in the south-eastern end of the Delta.

The multi-decadal hydrological variability in the Okavango Basin is most seen through the hydrograph of one of the rivers that drains the Okavango Delta the Thamalakane River (Fig. 3).

Although available data covers only the period of 1968-2009, there is a significant difference between the wet 1970 s and the dry 1990s, with the 1980s being transitional. The 2000 s seem to form the transition of the system back into the wetter phase, with the 2010 flows ranking amongst the highest on record. The pattern observed in the shorter record of the Thamalakane River corresponds to the analogous part of the dry-wet-dry-wet pattern present in the flows of the Okavango River as measured at Mohembo, upstream of the Okavango Delta (Fig. 2).

These wet and dry phases are caused by natural multi-decadal climate variability (Wolski et al. 2012; Jury 2009). Their potential impact are, however, exacerbated by changes in flow distribution between lateral parts of the Okavango wetlands as a result of geomorphological and vegetation processes leading to channel aggradation and blockages or possibly neotectonic events (Ringrose et al., 2006).

The history of shifts in distribution of the Okavango floodwaters is well documented (Ellery and McCarthy 1994; Wilson 1973). Recently, a shift occurred in 1997 between the Thaoge and Xudum river sub-Basins, increasing flows towards Toteng and Lake Ngami from that year onwards. Thus, in recent years, inundation and flows in this river system are proportionally larger compared to those observed in the Boro/Thamalakane/Boteti (Khumaga) and Santantadibe/Gomoti (Shorobe) river systems. However, available data are not sufficient to pinpoint the causes of the shift in inundation distribution. There is a possibility that shifts of a similar nature are likely to occur in the future.

\section{Livelihoods and socio-economic and political change}

The Okavango Delta wetland and the outflowing rivers (such as the Boteti) provide a lifeline for the majority of people living in the catchment area. In the study area land-use is characterised by a mix of natural rangelands, wildlife management areas, flood-recession and dry-land cultivation and areas that are used for human settlement and infrastructure. Tourism is another important land-use type. The wildlife-rich Delta wetlands are, in fact, of extremely high value on account of the multimillion dollar international tourism sector that they support. Nevertheless, the majority of the people in the Okavango Delta are poor (Statistics Botswana 2011) as tourism income is unevenly distributed. For instance, the proportions of the people below the poverty datum line were estimated at $47.3 \%$ and $27.9 \%$ in Ngamiland West and Ngamiland East, respectively, compared to the national figure of $20.7 \%$ (Statistics Botswana 2011). Taking into consideration the fact that Botswana is a middle income country with a gross national income per capita of USA\$ 6890 (2010), these Fig.s suggest that economic growth has only been moderately transformed into poverty reduction (World Bank 2012).

Since historical times, the Delta 


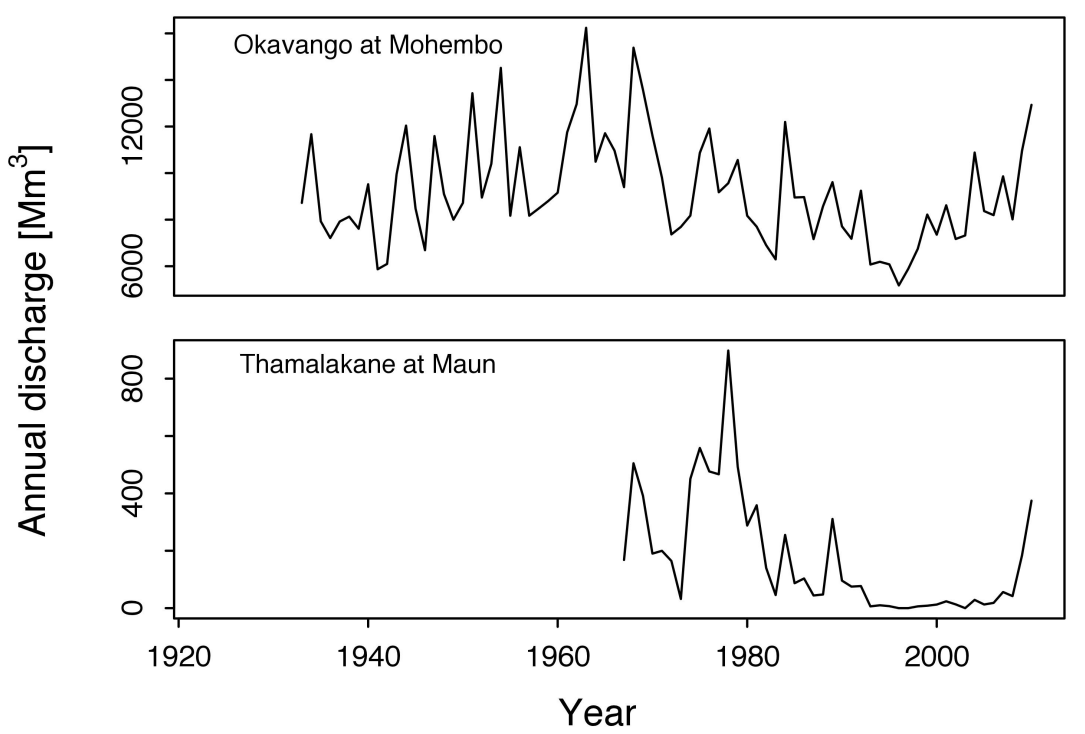

Fig. 3: Time series of annual discharge of the Thamalakane River and Okavango River at Mohembo in million cubic metres (Mm3).

inhabitants have used the wetland resources of the region to sustain their livelihoods through hunting and fishing, crop-farming and livestock herding (Tlou 1985). Presently, many subsistence activities have continued to be pursued by people in rural areas (and others in urban areas who keep a foot in the village). These include molapo farming, smallscale livestock husbandry as well as bushproduct harvesting (for example for building materials) and these activities are important to sustain a livelihood baselevel for many. Cash-income is, however, increasingly required for clothing, transport, mobile phones and food.

Another major factor that has influenced the region is population growth which has more than trebled. The population of the Ngamiland District increased by $226 \%$ from 42500 in 1964 to 138500 in 2006, while the population of the mid-Boteti area increased by $65 \%$ from 17400 in 1981 to 28700 in 2006 (Central Statistics Office [CSO] 2009). Other changes that have affected the study region include human diseases such as HIV/AIDS and animal diseases such as cattle-lung disease and foot-and-mouth disease (Kgathi et al. 2007). The current HIV/AIDS prevalence rate in Ngamiland is $17 \%$ (CSO 2009). The cattle-lung disease of 1995/96 resulted in the culling of the entire cattle population (over 300 000) of Ngamiland (Bendsen and Meyer 2003). Thus, households continue to be affected by environmental shocks and they adapt in various ways.

Adaptation to desiccation of the
Okavango-Boteti wetlands must thus be seen in the perspective of these other major changes. What is important to determine is whether adaptation of people and households results in positive outcomes in terms of people's livelihood security or at least not a reduction of such security. Adaptation to desiccation is crucial for households and communities that rely mostly on water-related livelihood activities with limited alternatives. Principally, these include households involved in flood-recession crop-farming, fishing or livestockherding.

People in rural areas of semi-arid Africa live in a context of high climatic variability. In the Okavango Delta, too, increasing numbers of people, especially younger men and women, have moved from rural areas to larger villages and towns such as Rakops, Letlhakane, Seronga, Shakawe, Gumare and, particularly, Maun to find services and salaried jobs. Over half of the regional population now lives in these settlements. The daily activities of most people today focus on earning money to buy food rather than growing and harvesting it and to buy building materials rather than collecting them from the bush. This has resulted in important changes in people's lifestyles.

\section{Specific study sites}

The villages selected as study sites are Khumaga, Shorobe and Sehitwa which are located in different parts of the Okavango wetland. Table 1 shows the population of these villages. While the population in the villages of Khumaga and Shorobe increased during the intercensal decades 1981 to 1991 and 1991 to 2001 the population of Sehitwa has not increased. These villages had different flooding and drying regimes over recent decades.

Shorobe village is located in the eastern part of the Okavango Delta where there is the Gomoti River. In the 1950s, 1960s and 1970s flooding, although irregular and always somewhat unpredictable, was nevertheless frequent enough to allow cropping of extensive areas (Baier, 2003). The unpredictability of the flooding patterns was the main reason why the German funded molapo development project focused on Shorobe in order to regulate flooding through the construction of various flood-control structures such as sluice-gates, bunds and small canals. This was quite successful for a brief period until in the late 1980s when the Gomoti River, which fed the Shorobe molapo farming areas, gradually dried up. The Gomoti River flood waters returned after 2004, but the water works constructed under the German project were in disrepair and mostly ineffective. Farmers were also instructed by officials of Department of Water Affairs to remove remaining bunds and other structures to prevent obstruction of the free flow of the water. In the year 2010, flood-levels around Shorobe were so high that most molapo fields were submerged throughout the planting season, while

Table 1: Population in the study villages in 1981 and 2001. Source CSO (2002).

\begin{tabular}{ccccc}
\hline Village & $\begin{array}{c}\text { Village proper } \\
\mathbf{1 9 8 1}\end{array}$ & $\begin{array}{c}\text { Village and } \\
\text { associated } \\
\text { localities 1981 }\end{array}$ & $\begin{array}{c}\text { Village proper } \\
\mathbf{2 0 0 1}\end{array}$ & $\begin{array}{c}\text { Village and } \\
\text { associated } \\
\text { localities 2001 }\end{array}$ \\
\hline Khumaga & 291 & 683 & 925 & 1252 \\
Shorobe & 539 & 2021 & 955 & 3333 \\
Sehitwa & 1452 & 6024 & 1478 & 5290
\end{tabular}


inhabitants of some localities (e.g. Ditshiping) were evacuated.

The village of Sehitwa is located near Lake Ngami, which has experienced extended periods of high and low (and dry) water levels. Before 2004, an extensive dry period lasted for about 20 years, but since then flooding of the lake has been regular. In the $1980 \mathrm{~s}$, there was molapo farming along the lake but this activity has shifted upstream. The lake is also important for fishing and cattle watering. Recently, there were plans to initiate bird-tourism in Lake Ngami, an important bird breeding area which attracts vast numbers of ducks, waders, flamingo and pelican. Many households in the Sehitwa area rely on livestock for their livelihood. Therefore, access to land and drinking water is important. Under conditions of varying floods, there is shifting availability of both grazing and water. Household adaptation to such shifts is important for livelihood security.

Khumaga is a small river village that experienced drying up of the river in the early 1990s. Earlier, in the 1970s, when the Makgadikgadi Pans National Park was proclaimed, villagers lost access to grazing and hunting/gathering lands across the river. Effectively, this proclamation reduced accessible land by $50 \%$, although for many years people informally continued to use this land. This continued till 2002, when an electric fence was constructed to prevent wildlife (especially elephant and lion) from straying into the villages, arable lands and cattle-posts. This fence also effectively prohibited any access by people or their livestock to the Park.

\section{Data Collection and Analysis}

\section{Satellite images and aerial photographs}

Satellite images, aerial photographs, and existing literature were used to determine the extent of channel desiccation in the study areas. For the overall study area and study sites, flooding patterns were examined for the 1980s, 1990s and 2005, using map data, aerial photographs (1983, 2001) and satellite imagery (Landsat, MODIS). This resulted in desiccation and flooding histories for the study areas that could be related to land-use changes. All data were captured in a Geographic Information System (GIS) database and added to the existing Okavango Delta
Information System (ODIS) which is housed at the Okavango Research Institute of the University of Botswana in Maun.

\section{Household survey and focus group discussions}

A structured questionnaire directed to heads of households was used to collect primary data in the study sites. It included household demographic information, household attributes, livelihood activities and sources of income, household use of the river, effects of river drying on the provision of ecosystem services, household adaptation to river drying, economic cost of adaptation practices and respondents' perceptions on factors influencing adaptive capacities. After the questionnaire was designed, it was pretested among 20 households at a small village called Toteng, in Ngamiland District, in order to ensure its plausibility. The questionnaire was then revised. Three research assistants were trained to administer the questionnaires.

Prior to sampling, a household listing was done in each village. The household recording led to a sampling frame of 323 households in Shorobe, 273 households in Sehitwa and 354 households in Khumaga. From each sampling frame, a random sample of $30 \%$ of the total number of households was selected. Thus, a $30 \%$ sample in this case represented a total of 255 households. The household survey was conducted during the months of September, October and November 2010.

In addition, focus group discussions were held with groups of 10-15 respondents in each of the three sites. Members of the group were identified during the interviews as having detailed or in-depth knowledge of issues researched on. The discussion in the group was guided by a semi-structured questionnaire. The purpose of the discussion was to have an in-depth understanding of some of the issues as well as to verify some of the data collected during household interviews.

Household survey data was analysed in the form of cross tabulations between variables (e.g. education of respondents and gender of respondents, livelihood activities pursued in different research sites) and charts (e.g. education level of respondents, respondent perception on factors affecting adaptive capacity). The Chi-square Test of independence was performed to detect association between variables in cross-tabulations.
Three types of adaptive costs were estimated. The first estimate was the cost of avoided death of livestock due to drying and loss as a result of livestock going astray in search of water during the dry spell. Some of the farmers avoided these costs by drilling boreholes for the supply of water. Most farmers, however, could not remember the capital costs of drilling boreholes as these were drilled or dug many years ago. The current prices of drilling and equipping a $50 \mathrm{~m}$ deep borehole in the study area were obtained from a local company called Water Africa. The second cost estimate was the opportunity cost of driving cattle to areas with water. To estimate the opportunity cost of driving cattle to other areas with water, the minimum wage rate in the agricultural sector was used. The third cost estimate was the economic loss associated with switching from flood recession farming to dryland farming. Information on existing literature was used to make the estimation.

\section{Assessment of the likelihood of desiccation and future implications}

An assessment of future inundation and flow conditions in relation to those observed today and in the past was undertaken in the study sites of Shorobe, Sehitwa and Khumaga in the context of anthropogenic climate change. Therefore, hydrological models of the Okavango River were run. These models were driven by rainfall and temperatures obtained from an ensemble of General Circulation Models (GCM), simulating past (20th century) climate under observed greenhouse gas (GHG) concentrations and future (21st century) climate change under projected GHG concentrations. Data from 19 GCMs from the World Climate Research Programme and other databases (CMIP3, Meehl et al., 2007) were utilised and for each GCM run, hydrological simulations were performed for a continuous period of 170 years (19302100). In this way, we obtained an ensemble of continuous series of hydrological responses corresponding to the past (1930-2000) and future (20012100) climate conditions simulated by GCMs.

To determine the socio-economic implication of desiccation, the following three scenarios were developed: 1) business as usual 2) pessimistic desiccation and 3) mining development. 




Fig. 4: Lake Ngami levels (1848 - 2009).

A total of ten policy-makers and researchers working in the area of climate change and variability in Botswana were interviewed in the months of January and February, 2013 using open-ended questionnaires with questions related to these scenarios. In scenario 1, business as usual scenario, it was assumed that the frequency and intensity of desiccation will remain the same. The respondents were asked how households will adapt in the future. In scenario 2, pessimistic scenario, it was assumed that desiccation will increase in frequency and intensity in the future. The respondents were again asked how households would adapt to the impacts of desiccation in the future. In the third scenario, it was assumed that desiccation will increase in frequency and intensity but mining will be successfully developed. The respondents were asked whether they thought mining development would offset the adverse effects of desiccation on livelihoods.

\section{Results}

\section{Satellite images, aerial photographs and literature}

\section{Lake Ngami}

Until about 130 years ago, much of the Delta waters flowed down the western Thaoge channel, flooding the western grasslands around Tubu, Habu, Nokaneng and Tsau and filling Lake Ngami, which was an impressive lake at the time of Livingstone's (1849) and Anderson's (1854) visits (Shaw 1983). In about 1883 the Thaoge channel became progressively blocked by vegetation and started to dry up, leading to the drying of Lake Ngami. Since then, there has been a succession of dry (or almost dry) and wet (in terms of a large lake) periods (Fig 4). Dry periods occurred from 1884 to 1897 and during 1905-09, 1911-20 (almost 15 years), 1934-36, 1938-47 (i.e. almost 13 years), 1989-2004 (another 15 years), while large lake extents were seen in 1898-99, 1904, 1925-26, 1968-69, 1978-79 (i.e. usually a period of two years following very high flood episodes). Intervening years were characterised by low lake levels (Shaw, 1983).

After 1996 the flow shifted to the Xudum channel system and from 2004 high floods pushed water through the Kunyere channel to once again fill Lake Ngami. Lake levels have been moderate since then with the highest (historically quite high) levels attained in 2010 and 2011.

From the historical record, it thus appears that a dry or low lake level is the norm rather than the exception, with dry episodes generally lasting longer than high lake level episodes. Over these historic times people have coped with these changes within the context of traditionally diversified household livelihood systems. However, current conditions of rapid population growth and land-use change that result in reduced access to 'spare' land, important during times of drought and stress, have an undermining effect upon household adaptive capacity.

\section{Shorobe}

Desiccation is also a natural phenomenon of the Shorobe floodplains and surrounding areas that are fed by the
Gomoti channel. In 1922, the Gomoti was the major perennial river in the eastern Delta (Bernard and Moetapele, 2005) and this continued into the late 1930s. Since then, the Gomoti River has been progressively drying and has reached its mouth (at the Thamalakane) only roughly once per decade from the mid-1940s (Bernard and Moetapele, 2005). However, the Shorobe floodplains can also receive flood waters from the Santantandibe and Boro-Thamalakane channels because the low relief allows the Thamalakane to be a two-way river that can flow in both directions. This happened during the high flood years of the 1960s and $70 \mathrm{~s}$ and into the 1980s, after which low flood levels cut off that supply of flood waters. The flood-plains remained dry and were subjected to desiccation. This changed only after 2004

Table 2: Summarised flow record of Boteti River at Rakops, 1849-present. Source: Breyer (1983); DWA (2002).

\begin{tabular}{|c|c|}
\hline Year & Flow condition \\
\hline $2010-2012$ & Flow \\
\hline 1991 - 2009 & Dry \\
\hline $1989-1990$ & Flow \\
\hline 1987 - 1988 & Dry \\
\hline $1984-1986$ & Flow \\
\hline 1983 & Dry \\
\hline $1974-1982$ & Flow \\
\hline 1973 & Dry \\
\hline $1966-1972$ & Good flow \\
\hline 1965 & Poor flow \\
\hline 1961 - 1964 & Good flow \\
\hline 1960 & Poor flow \\
\hline $1952-1959$ & Good flow \\
\hline 1948 - 1951 & Low flow \\
\hline 1941 - 1947 & Dry \\
\hline 1940 & Poor flow \\
\hline 1929 - 1939 & Dry \\
\hline 1901 - 1928 & Flow (high flood) \\
\hline 1900 & Dry \\
\hline $1849-1899$ & Flow \\
\hline
\end{tabular}






Fig. 5: Flooding in the Boteti River during the period 2000-2009.

when renewed high flood levels pushed water into the floodplains, initially from the Boro-Thamalakane system, later through the Santantadibe and, since 2009, once more through the Gomoti channel. In 2010, the Gomoti floods were so high that most molapo farms remained inundated throughout the planting season of 2010-11 so that crop cultivation was impossible.

\section{Khumaga}

Floodplains in the Boteti River in the Khumaga area are small and scattered compared to those near Shorobe or Lake Ngami (Fig. 4). In fact, the better locations for molapo farms are at some distance south and west of Khumaga village, where the Boteti River-bed is incised and rather narrow.

The Boteti River is a variable ephemeral river with periods of 'good' flow and periods of no flow (Table 2). The water level at Khumaga is not recorded. The nearest stations are at Rakops (70 km south) and at Samedupe (200 km upstream). The most recent dry spell at Rakops started in 1991 and in Khumaga a year later. The Boteti River started to flow beyond Chanoga after 2006 (Fig. 5), reached beyond Khumaga for the first time in 2009. The majority of people who are alive today have experienced only a dry river.

\section{Household survey and focus group discussions}

\section{Livelihood activities}

The livelihood activities of the households were quite diverse (Fig. 6).
Most of the households were involved in more than one activity. This is an obvious advantage, which enhances their adaptive capacity. Dryland farming was the most important livelihood in the villages of Shorobe and Khumaga, where the WaYei are the predominant ethnic group, whereas livestock farming was the predominant livelihood activity in the village of Sehitwa, where the OvaHerero are the dominant ethnic group. Therefore, ethnicity is a major determinant of access to livelihood activities in the Okavango Delta, including the distal parts of the Boteti River sub-Basin. These results are consistent with those of other studies in the Okavango Delta (Kgathi and Motsholapheko 2011; Bendsen and Meyer 2003).

\section{Use of the river channels}

The Okavango River channels, including those of Boteti River, provide important ecosystem services for the people in its basin. Important services are those of water supply for domestic use, livestock drinking, brick-moulding, vegetable gardening, fishing and floodplain farming. Focus group discussions revealed that these channels are also sources of medicinal plants, ornamental products, basket-making raw materials, wild fruits and a grazing ground for livestock. They further revealed that the community and households in Khumaga uses the river for important cultural services such as baptism and traditional healing practices. Furthermore, the river provides a means for boat transport to nearby villages. In Khumaga, the villagers also reported that they obtained game meat from wild animals trapped by mud in certain lagoons in the river.

\section{Effects of channel drying on the provision of ecosystem goods and services}

An elderly respondent in Khumaga indicated that the longest time he remembered when the Boteti River dried was for 15 years prior to 1947 , and thereafter it flowed and dried for short periods in subsequent years. Forty three percent $(43 \%)$ of respondents in this village indicated that they experienced the drying of the river in the 1990's. Three elderly respondents in Shorobe and one elderly respondent in Sehitwa said the drying of the river channels had been experienced in the 1950's. The perceptions of the respondents on the 


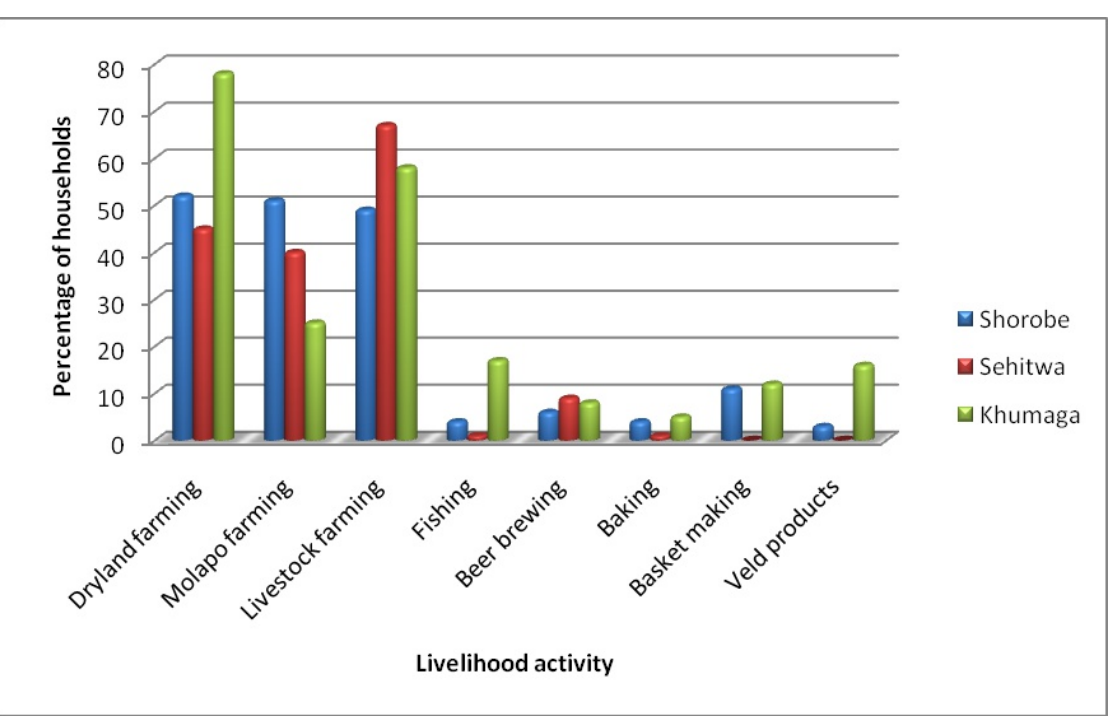

Fig. 6: Livelihood activities of households in the villages of Shorobe, Sehitwa and Khumaga.

causes of the drying of the river channels in the three villages included human induced changes $(15 \%)$, decrease in rainfall and increased evaporation (33\%).

The rest of respondents said they did not know what really caused channels to dry up. As most households are dependent on the river for different livelihood activities, they were adversely affected when the river dried. The river provides water, a very important ecosystem service on which a number of livelihood activities are based in the Okavango Delta. In Shorobe a high proportion of the households $(43 \%)$ said their flood recession cultivation (43\%) was adversely affected by desiccation, whereas in Sehitwa and Khumaga villages, the most affected activities were flood recession farming and livestock farming, respectively (Table 3). Focus group discussions revealed that farmers' cattle died as a result of lack of water during the dry spell. Other farmers lost their cattle as the animals went astray in search of water and grazing. The drying of the river channels also resulted in loss of provisioning services such as water lily (Nyamphaea nonchali) and river reed (Phragmites sp.), used as construction material.

\section{Household adaptive strategies to channel desiccation}

Households had various mechanisms for coping with, or adapting to, channel drying. Those who lived in the periphery of the village, who did not have access to water in public stand pipes, relocated to areas with water during the dry spell, dug wells by hand, or obtained water from government-owned-boreholes. The Government invested in groundwaterbased village water supply schemes, therefore helping people to cope with the problem of water scarcity.

Coping and adaptation mechanisms for lack of drinking water for livestock included the following: 1) requesting for water from other households, 2) driving livestock to areas with water, 3) paying for accessing water for livestock, 4) creating water storages for livestock, 5) reducing the frequency of watering livestock, 6) drilling boreholes, and 7) digging hand-dug wells. A Chi-square Test of Independence revealed a significant association between gender and whether or not a respondent adapted to lack of water for livestock at $5 \%$ level of significance $\left(\chi^{2}(1)=12.25\right)$. Thus, the decision to adapt to channel desiccation with respect to lack of water was influenced by gender of the respondent. Male-headed households were more successful in adapting to lack of water than their female counterparts. In all the three study areas, the most common adaptation mechanism was digging a hand-dug well (13\%). Many households that adapted by digging hand-dug wells were from Khumaga village.

Household responses such as driving livestock to areas with water, paying for accessing water at other farmers' water sources, having water storage for livestock and reducing the frequency of watering livestock, represent short term responses to the problem of desiccation and could therefore be described as coping rather than adaptation strategies. Our discussions with farmers revealed that in most cases, farmers' short term responses are a result of lack of adequate resources to invest in long term strategies or they own too few livestock to justify undertaking a costly investment such as drilling a borehole. In responding to lack of water for molapo farming, $49 \%$ of the households switched from molapo farming to dryland farming. Focus group discussions also revealed that there were

Table 3: Proportion of households negatively affected by channel desiccation on various uses of water.

\begin{tabular}{lcccc}
\hline \multirow{2}{*}{$\begin{array}{c}\text { Change in ecosystem } \\
\text { service }\end{array}$} & \multicolumn{2}{c}{ Sites } & Overall percentage \\
\cline { 2 - 4 } & Shorobe (\%) & Sehitwa (\%) & Khumaga (\%) & 23.9 \\
\hline Domestic water use & 26.8 & 11.0 & 34.2 & 34.1 \\
Livestock drinking & 33.0 & 18.3 & 52.6 & 32.5 \\
Molapo farming & 43.3 & 28.0 & 23.7 & 7.1 \\
Brick moulding & 3.1 & 2.4 & 17.1 & 13.7 \\
Fishing & 14.4 & 1.2 & 26.3 & 1.2 \\
Vegetable gardening & 3.1 & 0.0 & 0.0 & 11.4 \\
Aquatic harvesting & 17.5 & 0.0 & 15.8 & 76 \\
$N$ & 97 & 82 & 255
\end{tabular}




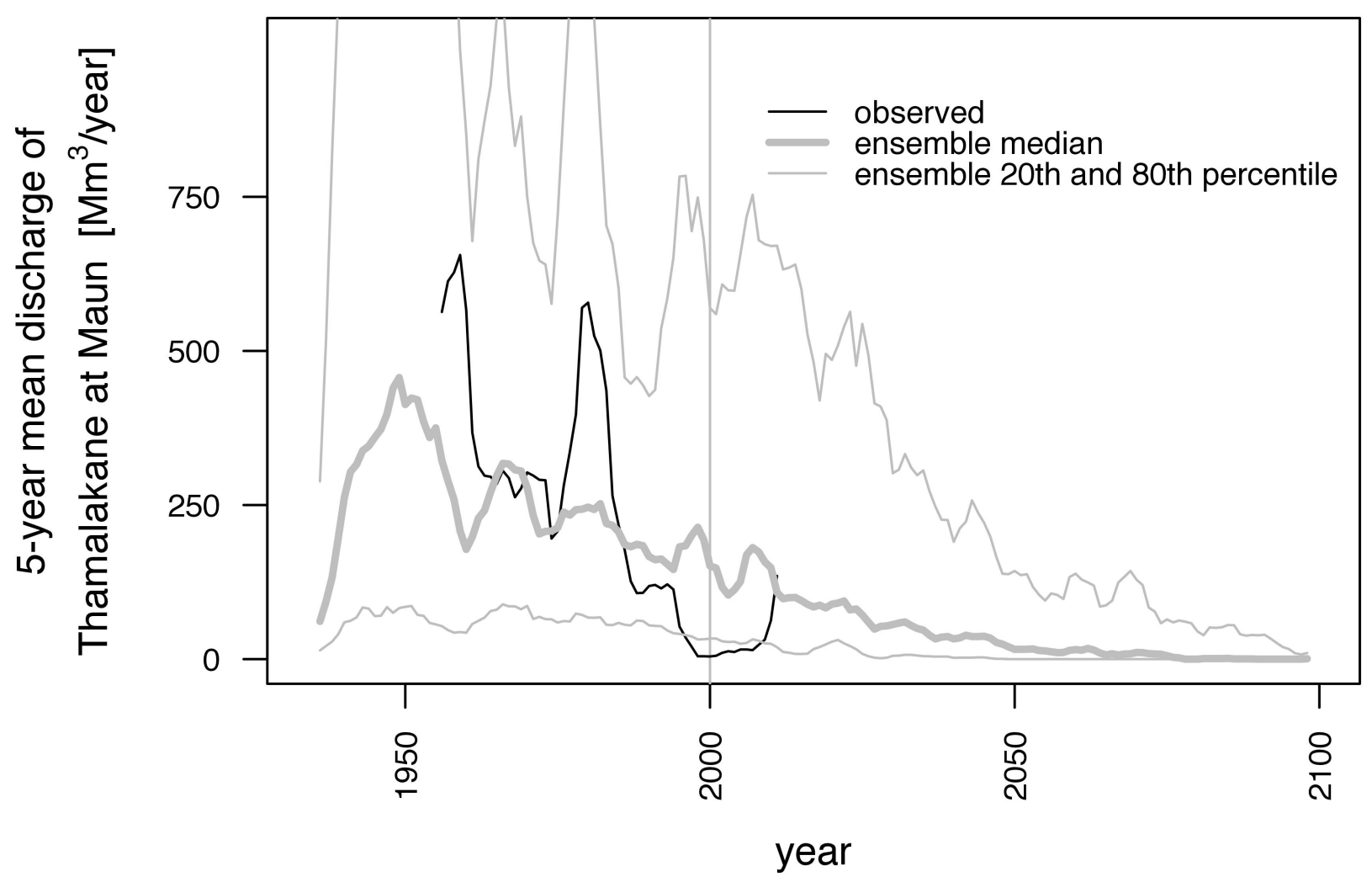

Fig. 7: Thamalakane River flows observed and $20^{\text {th }}, 50^{\text {th }}$ and $80^{\text {th }}$ percentile of ensemble simulations driven by GCM data for 20th and 21st century in million cubic metres $\left(\mathrm{Mm}^{3}\right)$.

households who owned and cultivated both molapo and dryland fields. Some of the households in Khumaga continued to cultivate their molapo fields after the river dried in 1992, but these were now fed only by rainfall. But they also adapted to changing circumstances by shifting emphasis on a variety of livelihood activities that included hunting and gathering, livestock and crop farming. After the return of the 2005 floods, most households in Khumaga and other villages in the Boteti River sub-Basin started flood recession cultivation.

\section{Costs and/or benefits associated with adaptation practices}

Having experienced the long-term problem of channel desiccation in these villages, some farmers were able to drill boreholes to have a sustainable water supply. Thus, by adapting to lack of water for livestock drinking, these farmers were able to avoid or prevent their livestock from dying. The average direct cost of drilling a borehole of $50 \mathrm{~m}$ depth in the study areas currently amounted to BWP 86000 (USA\$12 991 ). This excluded the cost of equipping the borehole.
Depending on the method for equipping the borehole, it cost a farmer about BWP 9000 for a submersible pump or BWP 33 000 for a mono pump. Thus, the capital costs ranged from BWP 95000 (USA $\$ 14$ 107.50) to BWP119 000 (USA $\$ 17671.50)$. The annual maintenance costs of the equipment ranged from $10-20 \%$ of the capital costs.

It was revealed during focus group discussions that farmers who could not drill a borehole due to lack of resources, paid those with boreholes to access drinking water for livestock. The yearly payment was in the form of a cow or its cash equivalence. In 2011, a cow was valued on average at BWP3 500 which translates to BWP291/month. However, this payment does not, however, take into account the size of the livestock herd that is supplied from the borehole. In most cases under this arrangement, a number of farmers would pay for accessing water from a single borehole, and each individual farmer would give a cow as per the terms of payment. Adaptation strategies such as driving cattle to other areas with water entail an opportunity cost. Most farmers who drove their livestock to water sources reported that, on average, they spent 5 hours daily on this activity. Using the minimum wage rate in the agricultural sector of BWP408/month, the annual opportunity cost of driving cattle to water points was estimated at BWP3 577 per farmer.

Switching from molapo to dryland farming during the dry spell causes farmers to incur losses in terms of yield. This is mainly because molapo farming has higher yields than dryland farming (Bendsen and Meyer 2003). However, this applies to farmers who discontinue cultivation of their molapo fields during the dry spell. Rashem (1988) estimated the average sorghum yield under molapo farming at $520 \mathrm{~kg} / \mathrm{ha}$. The average price of a tonne of sorghum in 2010 (Grade 1 and 2) was BWP117.50. Assuming that all factors that affect the yield of sorghum are constant, the failure of molapo farmers to plough therefore entails an estimated loss of BWP609.7/ha. This is considered a conservative estimate as the costs associated with the intercropping of sorghum with beans, maize, melons and other crops are not taken into consideration. 


\section{Future climate change and variability}

The results of the hydrological modelling based on an ensemble of Global Change Models (Wolski et al, 2012) indicates that future flows of the Okavango River will be considerably lower than those observed in the 20th century. In addition, the range of inter-annual and pluri-annual variability is simulated to be considerably lower than that observed in the past. For instance, an ensemble of simulations of the Thamalakane River flows at Maun, driven by the GCM rainfall and potential evapo-transpiration (PET) and simulated Okavango flows (Fig 7), indicates a pronounced reduction in flows. The projections also show that there is a pronounced reduction in the width of the 20th and 80th inter-percentile range. This indicates that in spite of the continued variability of flood levels, the long term trend is toward a reduced frequency of high flood levels. In other words, even though inter-annual and pluri-annual variability will still occur in the future, wet periods will not be as wet as they were in the 20th century. This means that floodplains such as those near Shorobe will be flooded less frequently, while the terminal rivers are projected to cease flowing towards the end of the 21st century. The same applies to the Boteti River. An increase in the frequency and severity of desiccation is likely to have adverse affects on most livelihood activities. Therefore, desiccation of the Okavango Delta and Boteti River systems has implications for future climate change adaptation. Currently, a range of strategies are adopted to adapt to the current hydrological and climate variability.

What then are the implications of the future climate variability and change on human livelihoods? To answer this question, the following three scenarios have been developed: 1) business as usual 2) pessimistic desiccation and 3) mining development. The scenario on mining has been included because this activity may lead to income generation. Desiccation has a negative impact on income generation, whereas mining development has a positive impact. In the business as usual scenario, it is assumed that the frequency and intensity of desiccation remain the same. It is therefore likely that the people of the Okavango Delta and Boteti River will continue to employ existing strategies to adapt to the problems of diminished water resources and river-based livelihood activities. The previous sections of this paper have revealed that most of the households in the study areas depend on river-based livelihood activities such as flood recession agriculture, fishing, collection of veld products, and livestock farming. These activities are therefore likely to be adversely affected by future climate change and variability. Some adaptive strategies such as livelihood diversification, migration, training in non-agricultural skills, and the identification and use of opportunities arising from desiccation will gradually become important. Other traditional adaptive strategies such as short- and long-term local mobility may in the long term become insufficient for dealing with the impacts of desiccation. Our interviews with policy-makers and researchers have indicated that although the current adaptive strategies will be effective in the short-term (20 years) under the 'business as usual' scenario, they may not be sufficient to alleviate the impacts of desiccation in the long-term (beyond 20 years). In addition to population growth and related land use restrictions, the limits to adaptation in the long term may include slow adoption of modern technology in farming, vulnerability emanating from high dependence on natural resources and public transfers which are susceptible to climatic variability and economic change, respectively.

In the case of the pessimistic desiccation scenario, the frequency of desiccation is assumed to increase, and thus water availability in the Okavango Delta and Boteti rivers will decrease due to reduced rainfall and flow of the river channels. As revealed by GCM data for this study, the severity of desiccation will increase in the future. The interviewees further revealed that the reduction in water supply as a result of desiccation may have a greater adverse effect on the supply of river-based ecosystem services such as fisheries, recreation and tourism activities, water for flood recession agriculture, and the collection and sale of veld products. In addition, yields from rain-fed agriculture are also likely to decline due to climate change, further worsening the already deteriorating food security situation in the Okavango Delta and the rest of Botswana (Ministry of Finance and Development Planning, 2009). Continued population growth and land use change will further undercut the adaptive capacity of households. The interviewees further suggested that the traditional adaptive strategies may in the short-term increasingly become ineffective and in the long-term render traditional livelihood activities unworthy to pursue. It is also expected that as the severity of desiccation increases, its impact will be felt more by the poor than wealthy households. This scenario can be avoided if appropriate measures are undertaken during planning as farmers have enough time to prepare for increased desiccation. As suggested in the interviews, more innovative strategies which foster adoption of new technology in farming, engagement in non-farm activities and identification of opportunities will become prominent in the future. Locally appropriate adaptive strategies can then be developed from indigenous knowledge to foster improved performance in dryland cultivation and eco-tourism

The mining development scenario assumes that in addition to an increase in the frequency of desiccation, mining projects in Ngamiland are successfully developed. There are good prospects for the development of copper mining in Ngamiland. The Boseto Mine is located in the Kalahari Copper Belt in Toteng, approximately $80 \mathrm{~km}$ south-west of Maun, the capital of Ngamiland. It was commissioned in June 2012. The halfyear financial report revealed that the mine made a loss of US\$ 14.6 million during the period ending in December 2012 and that it is currently employing 615 people in Botswana and Australia (Discovery Metals Limited 2012). There are additional employment opportunities in Ngamiland associated with backward linkages of the mine. Although the mine is currently making a loss due to a decline in copper prices, it is expected that the situation will be different in the future. The half year financial report made forward-looking statements about the mine. However, it made it clear that there are uncertainties about the future of the mine due to possible changes in market prices, availability of capital and finance and trends in economic development (Discovery Metals Limited 2012). The interviewees thought that if the financial situation of the mine changes in the future, employment opportunities created by the mine may benefit the local population of Ngamiland. This suggests that mining may compensate some of the desiccation induced losses in employment opportunities resulting from the adverse impacts on river-based ecosystem 
services. However, they pointed out that that the benefits associated with mining may be of a temporary nature since minerals are a non-renewable resource. In addition, the development of mining may be constrained by lack of water which is also likely to be worsened by desiccation. Water and power supply are considered to be major challenges facing the development of the mine (Discovery Metals Limited 2008, Mosikari 2011). Unlike other mines in the country which are connected to the national power grid, the Boseto mine generates its own power at a cost of USA $\$ 3.3$ million per year (Discovery Metals Limited 2009). There are on-going discussions about the possibility of connecting the mine to the national power grid in order to reduce its costs. Notwithstanding these challenges, development of the mine could well provide the necessary additional economic stimuli to overcome some of the desiccation related problems in the Okavango Delta.

\section{Discussion}

This paper has shown that desiccation of river channels has adversely affected ecosystem services supporting livelihood activities, particularly those based on provisioning services such as molapo farming, veld products collection, and livestock farming. According to Baier (2003), molapo farming around Shorobe area decreased from over 5,000 ha in 1983 to less than 800 ha in 2002 . Livelihood activities based on cultural services such as tourism have also been adversely affected by desiccation. It is also possible that supporting and regulating services have also been adversely affected as it has been shown that desiccation has adversely affected biodiversity which is the main source of ecosystem services. The paper has also shown that access to ecosystem services was mediated by a number of factors such as gender and ethnicity, and this is consistent with the findings of a number of studies in the Okavango Delta and other parts of the world (Kgathi and Motsholapheko, 2011, Daw et al. 2011).

The household survey has shown that in the past households responded to river channel desiccation through various strategies which became part of the way of living of the people over time. They can therefore be referred to as adaptive strategies as opposed to coping strategies. According to Nuorteva et al. (2010), livelihood diversification represents a strategic way of coping and adapting to environmental shocks. For instance, in response to channel desiccation, households engaged in other livelihood activities to avoid the effect of crop failure in the event of a bad flood-year (Scudder et al. 1993). However, ecosystem services-based livelihood diversification undertaken by households is faced with many challenges such as reduced availability of communal land due to population growth, land-use change in the region (e.g. converting communal land into private ranches) and the growing number of regulations governing the use of bush products, hunting and fishing. This suggests that in the future ecosystem services-based livelihood diversification will be a limited strategy for adapting to environmental change in the Okavango Delta.

In adapting to lack of water supply for livestock, households drilled boreholes in the study area. In Khumaga, an intermediate solution was the digging of wells in the (dry) river-bed. The drilling of boreholes for the supply of water for livestock is a long term response to desiccation. The coping strategies among farmers have also been found to be different due to differences in wealth status. Wealthy households are more likely to engage in more long-term and high investment adaptive strategies than poor households (Feenstra et al. 1998). This has been demonstrated by households who owned boreholes and those who could not afford to drill boreholes for supply of water in the study area. While this study did not reveal that female-headed households were more likely to be affected by channel drying than male-headed households, other studies, (e.g. Bradshaw 2004; Vincent et al., 2010) have argued that women are more vulnerable to the impacts of environmental change than men because they constitute a large proportion of the poor in communities that are highly dependent on local natural resources for their livelihood and have limited access to other resources, including credit, extension services, information and technology.

The livelihoods of people also depend on entitlements such as family or government support (Osbahr et al., 2010). Requesting for water from other members of the community reflects the presence of a strong kinship network that assists households in coping with environmental change (Smit and Wandel 2006). Osbahr et al. (2010) found that in some areas in South Africa and Mozambique, informal institutions as defined by kinship, neighbourhood and friendship offered individuals and households the opportunity to give and receive goods and services in times of difficulty such as when experiencing environmental shocks.

Our findings on hydrological modelling are consistent with those of other studies which state that in southern Africa, the severity and frequency of extreme events is likely to increase in the future (IPCC 2001). This study has revealed that desiccation of river channels will be more severe in the future than at present. In addition, inter-annual and pluri-annual variability will still occur in the future but wet periods will not be as wet as they are at present.

\section{Conclusion}

The main aim of this study was to investigate the impact of desiccation of the Okavango River channels on ecosystem services supporting human livelihoods in the Okavango Delta, Botswana. The study revealed that desiccation adversely affected various river dependent ecosystem services such as flood recession agriculture, livestock farming, veld products collection, and cultural services. Households adapted to desiccation in various ways, including driving livestock to areas with water, paying for water for their livestock, reducing the frequency of watering livestock, drilling boreholes, and digging hand-dug wells. High income households adapted to desiccation better than poor households.

In addition, the results of the hydrological modelling revealed that the future flows of the Okavango River will be lower than those observed in the 20th century. Although interannual and pluriannual variability will still occur in the future, wet periods will not be as wet as they were in the 20th century. Reduced channel desiccation is likely to increase poverty among households, and this may adversely affect access to ecosystem services and therefore worsen well-being as predicted by our conceptual framework.

These results may assist policy-makers in formulating strategies for future climate change adaptation. For instance, adaptation policies which support diversification of livelihood activities into those which are less dependent on 
ecosystem services could be promoted. As demonstrated by our scenarios, there is a possibility that the development of mining could reverse the de-diversifying effect of desiccation of river channels on rural livelihoods in the future in the Okavango Delta. In addition, key ecosystem-based economic sectors such as tourism could continue to be developed. However, the impact of these livelihood activities will depend of the magnitude of desiccation. In conclusion, the results of this research may also provide useful lessons for policy-makers in wetlands with similar conditions throughout the world.

\section{Acknowledgements}

This paper is based on the research report prepared for the System for Analysis Research and Training (START) by the authors of this paper. DLK took the lead in transforming the report into this paper. His main contribution was on the sections on conceptual framework and key concepts, and future climate change and variability. $\mathrm{He}$ also marginally contributed to the section on household survey and focus group discussions. GM was the coordinator of the START research project and immensely contributed to the drafting of the original report, especially the sections on conceptual framework and key concepts, and household survey and focus group discussions. CV mainly contributed to the section on satellite images and aerial photographs while PW contributed to the section on future climate change and variability. MM contributed to the section on future climate change and variability. Finally, this research was generously funded by START through its 2010 Grant for the Global environmental Change Research in Africa and we are most grateful for their assistance. Finally, we would thank the following for their assistance: 1) Mr Edwin Mosimanyana, Research Scholar in Hydrology, for his useful comments on the paper and 2) $\mathrm{Mr}$ Charles K. Kabomo, GIS Specialist, for the preparation of the maps and 3) the anonymous reviewers for their critical comments on this paper.

\section{References}

Adger, W.N., Agrawal, S., Mirza, M.M.Q., Conde, C., Obrien, K., Pulwarty, R., Smit, B. and Takahshi, K. (2007): Assessment of adaptation practices, options constraints and capacity. In: M.L Parry, O.F Canziani, J.P Palutikof, P.J. van der Linden and C.E Hanson (Eds), Climate Change 2007: Impacts, adaptation and vulnerability. Contribution of Working group II to the fourth Assessment Report of the Intergovernmental Panel on Climate change. - Cambridge: Cambridge University Press.

Adger, W.N., Huq, S., Brown, K., Conway, D., Hulme, M. (2003): Adaptation to climate change in the developing world. - Progress in Development Studies 3: 179-195. CrossRef

Ashley, and Carney, D. (1999): Sustainable livelihoods: lessons from early experience. London: Department for International Development (DFID).

Baier, S. (2003): GIS-supported analysis of land use changes in the Shorobe area. MSc Thesis. Anhalt University, August 2003

Bendsen, H., Meyer, T. (2003): The Dynamics of Land Use Systems in Ngamiland: Changing Livelihoods Options and strategies. Available from: http://www.Okavangochallenge.com

Bernard, T., Moetapele, N. (2005): Desiccation of the Gomoti River: Biophysical process and indigenous resource management in Northern Botswana. - Journal of Arid Environments 63: 256-283. CrossRef

Boyd, J., Banzhaf, H. S. (2006): What are ecosystem services? The need for standardized environmental accounting units. Resources for the Future, Discussion Paper No RFF DP 06-02. Available from SSRN: http://ssrn.com/abstract=892425.

Bradshaw, S. (2004): Socio-economic impacts of natural disasters: a gender analysis. United Nations Office, Santiago

(http://www.eclac.org/mujer/ reuniones/conferencia regional/ manual.pdf (Date accessed 4/11/2010).

Callaway J.M. (2003): Adaptation benefits and costs-measurements and policy issues. Organisation for Economic Cooperation Development Available from: http://www.oecd.org/dataoecd/9/58/2482 290.pdf

Costanza, R., d'Arge R., De Groot, R., Farber, S., Grasso, M., Hannon, B., Limburg, K., Naeem, S., O'Neill, R.V., Paruelo, J., Raskin, R.G., Sutton, P. and van den Belt, M. (1997): The value of the world's ecosystem services and natural capital. - Nature 387: 253-260. CrossRef

Central Statistics Office (2002): National population and housing census. Gaborone: Ministry of Finance Development Planning.

Central Statistics Office (CSO) (2008): Botswana Census Based Poverty Map Report, Gaborone.

Central Statistics Office (2009): Botswana
Demographic Survey, 2006. Gaborone. Central Statistics Office (2009): Botswana AIDS Impact Survey III- BAIS III. Gaborone.

Daw, T., Brown, K., Rosendo, S., Pomeroy, R. (2011): Applying the ecosystem services concept to poverty alleviation: the need to disaggregate human well-being. -Environmental Conservation 38(4): 370-379. CrossRef

Dessler, A.E. and Parson, E.A. (2006): The Science and politics of global climate change. Cambridge: Cambridge University Press.

Discovery Metals Limited (2008): Bosetu Copper Project Annual Report (2008) ( http://www.discoverymetals.com.au/irm/ Company/ShowPage aspx?CPID $=1088$ \&EID=93093320) Date accessed 16/02/2011.

Discovery Metals Limited (2009): Boseto Copper Project BFS Economic Update. Brisbane: Discovery Metals Limited.

Discovery Metals Limited (2012): Half year financial report. Brisbane: Discovery Metals Limited.

Ellery, W. N., McCarthy, T.S. (1994): Principles for sustainable utilization of the Okavango Delta ecosystem, Botswana. - Biological Conservation 70: 159-168.

Ellis, F. (2000): Rural livelihoods and diversity in developing countries. Oxford: Oxford University Press.

Feenstra, J.F., Burton, I., Smith, J.B., Tol, R.S.J. (1998): Handbook on methods for climate change impact assessment and adaptation strategies. Amsterdam: UNEP/Vrije Universiteit .

Fussel, H.M. and Klein, R.J.T. (2006): Climate change vulnerability assessments; an evolution of conceptual thinking. - Climate Change 76: 301-329. CrossRef

Intergovernmental Panel on Climate Change (2001): Climate change 2001: impacts, adaptation and vulnerability. Cambridge: Cambridge University Press.

Jury, M. (2010). Climate and weather factors modulating river flows in southern Angola. - International Journal of Climatology 30: 901-908.

Kelly, P.M., and Adger, W.N. (2000): Theory and practice in assessing vulnerability to climate change and facilitating adaptation. - Climatic Change 47: 325-352. CrossRef

Kgathi, D.L., Motsholapheko, M.R. (2011): Livelihood Activities and Income Portfolios in Rural Areas of the Okavango Delta, Botswana. - In: Kgathi, D.L., Ngwenya, B.N., Darkoh, M.B.K. [Eds.]: Rural livelihoods, risk and political economy of access to natural resources in the Okavango delta, Botswana. New York: Nova Science 35-54.

Kgathi, D.L., Ngwenya, B.N., Wilk, J. (2007): Shocks and rural livelihoods in 
the Okavango Delta. - Development Southern Africa 24: 289-308. CrossRef

Kroeger, T., Casey, F. (2007): An assessment of market based approaches to providing ecosystem services on agricultural land. Ecological Economics 64: 321-332. CrossRef

Meehl, G.A. et al. (2007): The Wcrp Cmip3 Multimodel Dataset - a New Era in Climate Change Research. - Bulletin of the American Meteorological Society $\mathbf{8 8}$ : 1383-1394. CrossRef

Mendelsohn, J.M., VanderPost, C. Ramberg, L., Murray-Hudson, M., Wolski, P., Mosepele, K. (2010): Okavango Delta: Floods of Life. RAISON, Windhoek, Namibia.

Millennium Ecosystem Assessment (2005): Ecosystems and human wellbeing: A framework for Assessment. Washington: Island Press.

Ministry of Finance and Development Planning (2009): National Development Plan 10. Government Printer, Gaborone.

Mosikari, O. (2011): US\$180 m for Boseto copper project debt. The Botswana Gazette, Wednesday 16th February 2011.

Motsholapheko, M.R. (2013): Rural households and adaptation to flood variability in the Okavango Delta, Botswana. - PhD Thesis, university of Botswana (Deposited at the University of Botswana Library)

Munasinghe, M. (2008): Mainstreaming and implementing the Millennium Ecosystem Assessment results by integrating them into sustainable development strategy: Applying the Action Impact Matrix Methodology.

Nelson, G. C., Bennett, E., Berhe, A. A., Cassman, K., DeFries, R., Dietz, T., Dobermann, A., Dobson, A. R., Janetos, A., Levy, M., Marco, D., Nakicenovic, N., O'Neill, B., Norgaard, R., Petschel-Held, G., Ojima, D.,Pingali, P., Watson, R., Zurek, M. (2006): Anthropogenic drivers of ecosystem change: an overview. Ecology and Society 11(2): 29. URL: http://www.ecologyandsociety.org/vol11/i ss2/art29/

Nuorteva, P., Keskinen, M.and Varis, O. (2010): Water, livelihoods and climate change adaptation in the Tonle Sap Lake area, Cambodia: learning from the past to understand the future. - Journal of Water and Climate Change 1: 87-101. CrossRef

North, D.C. (1989): Institutions and economic growth: A historical introduction. - World Development 17: 1319-1332. CrossRef

Opschoor, J.B. (2008): Environment and poverty: perspectives, propositions, policies. In: Pantsers, W.G., ed "The Troubled Triangle: unravelling the linkages between inequality, pluralism and environment. Rosenberg, Amsterdam: 105-127.
Osbahr, H., Twyman, C., Adger, W. N. and Thomas. D. S. G. (2010): Evaluating successful livelihood adaptation to climate variability and change in southern Africa. - Ecology and Society 15(2): 27.

Panayotou, T. (1993): The economics of environmental degradation: problems, causes and responses. - In: Markandya, A. Richardson, J. (Eds): Environmental economics, a reader. New York:. St. Martin's Press. 316-363.

Perrings, C., Folke, C., Maler, C.-G. (1992): The economics of biodiversity loss: the research agenda. - Ambio 21: 201-211.

Ringrose, S., Vanderpost, C., Matheson, W., Wolski, P., Huntsman-Mapila, P., Murray-Hudson, $M$ and Jellema, $A$. (2006): Indicators of desiccation driven change in distal Okavango Delta, Botswana. - Journal of Arid Environments 68: 88-112. CrossRef

Schneider, S.H., Semenov, S., Parwardhan, A., Burton, I., Magadza, C.H.D., Oppenheimer, M., Pittock, A.B., Rahman, A., Smith, J.B., Suarez, A. and Yamin, F. (2007): Assessing key vulnerabilities and risk from climate change. - In: Parry, M. L., Canziani, O.F., Palutikof, J.P., van der Linden, P.J., Hanson, C.E. (Eds.). Climate Change Impacts, adaptation and vulnerability. Contribution of Working group II to the fourth Assessment Report of the Intergovernmental Panel on Climate change. Cambridge: University Press.

Scudder T., Manley, R.E., Coley, R.W., Davis R.K., Green, J., Howard, G.W., Lawry, S.W., Martz, D., Rogers, P.P., Taylor, A.R.D., Turner, S.D., White, G.F. and Wright. E.P. (1993): The IUCN review of the southern Okavango integrated water development project. Gland: IUCN.

Shackleton, C., Shackleton, S., Gambiza, J., Nel E., Rowntree, K. and Urquhart, P. (2008): Links between ecosystem services and poverty alleviation: Situation analysis for arid and semi arid land in southern Africa. Available from: http://www.unpei.org/PDF/preliminaryas sessments/Links-Ecosystem-Servicesand-Poverty-Alleviation.pdf accessed 10th June, 2009).

(Date Shaw, P. (1983): Fluctuations in the level of Lake Ngami: the historical evidence. - Botswana Notes and records 15: 79-84.

Smit, B., Burton, I., Klein, R.J.T., and Wandel, J. (2000): An anatomy of adaptation to climate change and variability. - Climatic Change: 45: 223-251. CrossRef

Smit, B., Wandel, J. (2006): Adaptation, adaptive capacity and vulnerability. Global Environmental Change 16: 282-292. CrossRef

Statistics Botswana (2011): Botswana core welfare indicators (Poverty) survey of 2009/10 preliminary results. Gaborone: Statistics Botswana

Stern, N., (2006): The economics of climate change. Cambridge: Cambridge University Press.

Tlou, T. (1985): A History of Ngamiland, 1750 to 1906 . The formation of an African State, Gaborone: MacMillan.

Umoh, U.T., Oladimej, A.A. and Kumar, S. (2004): Adaptation to the effects of climate change in southern Africa In: V.I Grover (ed). Climate change Five Years After Kyoto. Science Publishers Enfield.

Vincent, K., Wanjiru, L., Aubry, A. Mershon, A., Nyandiga, C., Cull, T. and Banda, K. (2010): Gender, Climate Change and Community-Based Adaptation: A guidebook for designing and implementing gender sensitive community based adaptation programmes and projects. New York: United Nations Development Programme.

Wallace, K. J. (2007): Classification of ecosystem services; problems and solutions. - Biological conservation 139: 235-246. CrossRef

Wilk, J., Kniveton, D., Andersson, L., Layberry, R., Todd, M.C. and Hughes, D.A. (2006): Estimating Rainfall and Water Balance over the Okavango River Basin for Hydrological Applications. Journal of Hydrology 331: 18-29. CrossRef

Wilson, B. (1973): Some national and man-made changes in the channels of the Okavango. - Botswana Notes and Records 5: 132-153.

Wolski, P. (2009): Assessment of hydrological effects of climate change in the Okavango Basin. Okavango Basin TDA technical report. Environmental Protection and Sustainable Management of the Okavango River Basin (EPSMO) project.

Wolski, P., Todd, M.C., Murray-Hudson, M. A., Tadross, M. (2012): Multi-decadal oscillations in the hydro-climate of the Okavango River system during the past and and under changing climate. Journal of hydrology 475: 294-305. CrossRef

World Bank (2012): World Development Report 2012. Washington DC: World Bank.

\section{Affiliations}

Donald L. Kgathi* (kgathi@mopipi. ub.bw), Moseki R. Motsholapheko (rmoseki@ori.ub.bw)

Okavango Research Institute

University of Botswana

P/Bag 285

Maun, BOTSWANA 
Piotr Wolski (wolski@csag.uct.ac.za)

Climate System Analysis Group,

University of Cape Town

Private Bag X3

7701 Rondebosch, SOUTH AFRICA

Gagoitseope Mmopelwa (gmmopelwa@ mopipi.ub.bw)

Department of Environmental Science,

University of Botswana

$\mathrm{P} / \mathrm{Bag} 0022$

Gaborone, BOTSWANA

Cornelis Vanderpost (cvanderpost@

outlook.com)

Centre for Applied Research

P.O. Box 70180

Gaborone, BOTSWANA

*Corresponding author 
